\title{
Fair and prompt
}

\section{THORU PEDERSON}

Department of Biochemistry and Molecular Pharmacology, University of Massachusetts Medical School, Worcester, Massachusetts 01605, USA

These are the two words that came to me, reflecting on the 20th anniversary of RNA. Of course, they are also both venerable doctrines in the law (yet often not met). They are founding and operating principles of RNA.

As a finishing PhD student in the spring of 1968 I submitted my first paper ("Use of Diphenylamine as a Colorimetric Reagent for RNA") to Analytical Biochemistry. A few weeks later, when I was at the Marine Biological Laboratory in Woods Hole, a letter arrived. It was from the editor and simply said "Your paper is accepted." No review(s). Thus did I begin to entertain the notion that maybe this was how submitting and publishing papers goes. Of course, as conveyed in the title of Arthur C. Clarke's sci-fi book "Childhood's End," my halcyon fantasy was soon dashed as I went on to submit and publish additional papers from both my $\mathrm{PhD}$ thesis and early post-doc days. As I recently thought about my experiences submitting to and publishing in $R N A$, having received Tim's kind invitation for us to offer perspectives, I quickly realized how very fair-minded and prompt the review process has always been. It has felt as if there has been an unwritten principle, perhaps there only sotto voce, that when any of our manuscripts is submitted, a sense of community prevails and that while no guarantees can or should be made, a spirit of camaraderie is there. This is what a journal founded by, and controlled by, the leaders of a profession is all about.
At the 1994 RNA Processing meeting in Madison, the building momentum for a journal culminated, as did the selection of an editor. There were antecedent factors, most notably the founding of the RNA Society a year earlier (if you haven't, do read Olke Uhlenbeck's engaging account in the August 2005 Society newsletter). The years have passed quickly and triumphantly. RNA has consistently been at the forefront of how our field has been evolving, whether with papers on the chemistry side (RNA atomic structure/catalysis) or on regulation (e.g., microRNAs), to mention only two of the more revolutionary dimensions of our field. Meanwhile, the journal has also kept pace with all the subfields that were breaking at the time of its founding, such as the dissection of the spliceosome (which had been previously constrained in the foggy hnRNP era), the fascinating world of alternative splicing, the small RNA-protein complexes such as the Ro RNPs, the beguiling array of RNA covalent modifications, and increasing coverage of cell biology-oriented papers on RNA (closest to my heart since the 1990s).

I am grateful to RNA for its editorial panache, which I have consistently seen as an author of research papers, as well of invited essays, meeting reports and book reviews (all subjected to review, as they should be), as well as when seeing the thoughtful decision letters on manuscripts on which I have been a referee. All done so well.

Happy 20th to our journal, and to our leader Tim!
Corresponding author: thoru.pederson@umassmed.edu

Article and publication date are at http://www.rnajournal.org/cgi/doi/ 10.1261/rna.049783.115. Freely available online through the RNA Open Access option.
(C) 2015 Pederson This article, published in $R N A$, is available under a Creative Commons License (Attribution-NonCommercial 4.0 International), as described at http://creativecommons.org/licenses/by-nc/4.0/. 

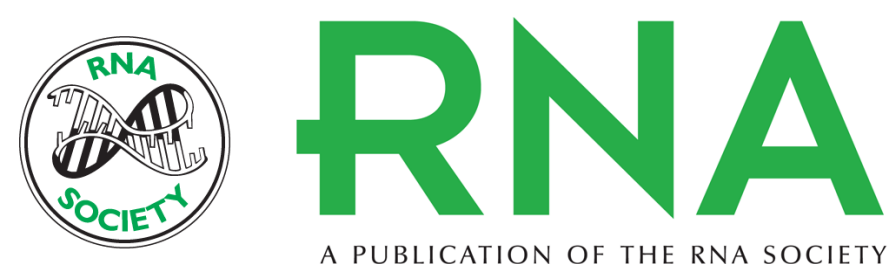

A PUBLICATION OF THE RNA SOCIETY

\title{
Fair and prompt
}

\author{
Thoru Pederson
}

RNA $201521: 711$
Open Access Freely available online through the RNA Open Access option.
Creative This article, published in $R N A$, is available under a Creative Commons License Commons (Attribution-NonCommercial 4.0 International), as described at License http://creativecommons.org/licenses/by-nc/4.0/. Email Alerting
Service

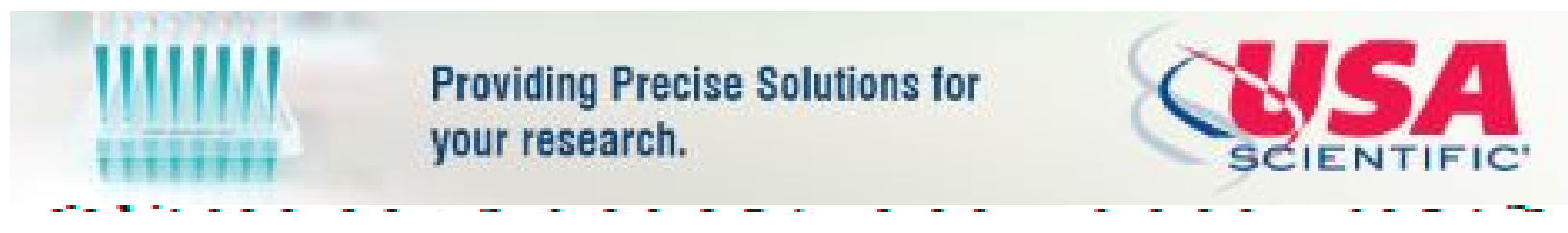

To subscribe to $R N A$ go to:

http://rnajournal.cshlp.org/subscriptions

(C) 2015 Pederson; Published by Cold Spring Harbor Laboratory Press for the RNA Society 